\title{
PERAN AUDIT INTERNAL DALAM UPAYA PREVENTIF FRAUD (STUDY KASUS PERUSAHAAN PERBANKAN YANG TERDAFTAR DI BEI)
}

\author{
Nurul Alfian \\ Fyanque89@yahoo.com \\ Runik Puji Rahayu \\ Runik@unira.ac.id
}

\begin{abstract}
Generally fraud prevention is only done on companies that have good internal control, but internal auditors also have an important role in the company, especially in terms of preventing fraud, internal audits are tasked with checking all parts or in the company whether they are in accordance with predetermined standards or not, and find solutions to problems that occur within the company.

This research is a qualitative descriptive study, which describes the data obtained from the banking company's annual report. The population of this research is banking companies listed on the IDX while the sample uses purposive sampling which produces four banking companies, namely, BNI, BRI, BTN, Bank Mandiri. In this study researchers used descriptive methods, where researchers describe or explain data obtained about the role of internal uadit in preventing fraud and comparing fraud prevention by auditors and what efforts have been made by banking companies in preventing fraud.

Internal audit has a very important role in preventing fraud. The internal audit of the four banks that were sampled was able to implement and carry out the prepared audit plan and provide recommendations that could solve the problems that occurred in that manner. All audit activities have been included in the audit charter and are governed by the directors' regulations. Of the four banks, there have been efforts in preventing fraud, among others, by providing a Whistleblowing system and a program to control gratification. For employees or other parties who commit fraud (fraud), sanctions are categorized into 3 types, namely minor, moderate and severe sanctions and sanctions in the form of administrative sanctions and financial sanctions.
\end{abstract}

Keyword: internal audit, fraud prevention

\section{ABSTRAK}

Umumnya pencegahan fraud hanya dilakukan pada perusahaan-perusahaan yang mempunyai pengendalian internal yang bagus, namun Auditor internal juga mempunyai peran penting dalam perusahaan terutama dalam hal mencegah terjadinya fraud, audit internal bertugas memeriksa semua bagian atau difisi dalam perusahaan apakah sudah sesuai dengan standart yang telah ditetapkan atau tidak, serta mencari solusi atas masalah yang terjadi dalam perusahaan.

Penelitian ini merupakan penelitian deskriptif kualitatif, yaitu menggambarkan datadata yang didapat dari annual report perusahaan perbankan. Populasi dari penelitian ini perusahaan perbankan yang terdaftar di BEI sedangkan sampelnya menggunakan purposive sampling yang menghasilkan empat perusahaan perbankan yaitu, BNI, BRI, BTN, Bank Mandiri. Dalam penelitian ini peneliti menggunakan metode deskriptif, dimana peneliti menggambarkan atau menjelaskan tentang data yang diperoleh tentang peranan uadit 
internal dalam mencegah fraud serta membandingkan pencegahan fraud oleh auditor da apa saja upaya yang telah dilakukan perusahaan perbankan dalam mencegah fraud.

Audit internal mempunyai peran yang sangat penting dalam mencegah fraud. Audit internal dari keempat bank yang dijadikan sampel tersebut bisa menerapkan dan menjalankan rencana audit yang telah disusun serta memberikan rekomendasi yang bisa menyelesaikan permasalahan yang terjadi diperbankan tersebut. Semua kegiatan audit telah dicantumkan dalam piagam audit serta diatur oleh peraturan direksi. Dari keempat bank tersebut sudah terdapat upaya dalam mencegah fraud antara lain sudah menyediakan wistleblowwing system dan program Awareness pengendalian gratifikasi. Bagi karyawan atau pihak lain yang melakukan penyimpangan ( $f r a u d)$ maka akan dikenakan sanksi dikategorikan ke dalam 3 jenis yaitu sanksi ringan, sedang dan berat serta terdapat sanksi berupa sanksi administratif dan sanksi finansial.

Kata kunci: Internal audit, Pencegahan fraud

\section{PENDAHULUAN}

Di era yang modern ini semakin banyak perusahaan-perusahaan yang berdiri di indonesia dan di kalangan internasinal, namun banyak juga perusahaan yang gagal mempertahankan kemajuannya dan bahkan pailit akibat banyaknya pihak yang melakukan kecurangan (fraud) seperti yang terjadi pada perusahaan internasional yaitu Enron, Worldcom, dan masih banyak lagi (sindonews.com). Akhir-akhir ini semakin banyak perusahaan-perusaan yang terlibat atau menjadi korban dari fraud tesebut, bahkan di indonesia sendiripun juga terdapat perusahaan-perusahaan yang melakukan kecurangan seperti yang terjadi pada paerusahaan bank century, thosiba, NSF Finance dan masih banyak lagi. Hal ini disebabkan oleh lemahnya pengendalian internal dalam perusahaan serta audit internal yang tidak berperan aktif yang mengakibatkan para pelaku kecurangan semakin mudah melakukan kecurangan tersebut. Hal ini tentu sangat merugikan perusahaan, untuk itu perlu adanya tindakan yang tegas dari pihak manajemen atau dari pihak auditor internal dalam upaya mencegah fraud.

Kecurangan bisa dicegah sedini mungkin dengan menerapkan perilaku jujur pada setiap orang, dalam sebuah perusahaan pencegahan bisa dimulai dari pimpinan, karena setiap perilaku seorang pemimpin akan ditiru oleh karyawannya. Jika seorang pimpinan sudah terlibat kasus kecurangan maka tidak menutup kemungkinan seorang karyawan akan melakukan hal yang sama karena dalam situasi seperti itu karyawan akan berfikir jika pimpinannya saja sudah melakukan kecurangan mengapa seorang karyawan tidak bisa melakukan kecurangan, hal ini akan menimbulkan rasa rasionalisasi dimana seorang pelaku akan membenarkan tindakannya sendiri. Untuk bisa meminimalisir kemungkinan kecurangan yang akan terjadi, sebuah perusahaan harus memiliki internal kontrol yang bagus. Kecuranga juga bisa dicegah dengan mengeliminasi kesempatan yang mungkin bisa dilakukan oleh pelaku kecurangan (Mark F. Zimbelman Dkk 2014).

Umumnya pencegahan fraud hanya dilakukan pada perusahaan-perusahaan yang mempunyai pengendalian internal yang bagus, serta pimpinan yang benar-benar sadar akan upaya dalam mencegah fraud. Jika dalam perusahaan sudah diterapkan pengendalian internal yang baik dan mempunyai kebijakan-kebijakan yang dijalankan dengan baik maka perusahaan tersebut sudah melakukan upaya pencegahan fraud dari segi kesempatan yang artinya kesempatan untuk melakukan fraud sudah diminilisir sehingga para pelaku fraud tidak akan mempunyai kesempatan untuk melakukan fraud tersebut. Perusahaan juga bisa melakukan beberapa upaya lain dalam mencegah fraud seperti melakukan pelatihan mengenai fraud bagi manajer dan menyediakan tips anti fraud secara online bagi karyawan, serta menyediakan tempat pelaporan bagi karyawan atau pihak lain yang menemukan gejala- 
gejala terjadinya fraud (fraudster.weebly.com). Auditor internal juga mempunyai peran penting dalam perusahaan terutama dalam hal mencegah terjadinya fraud, audit internal bertugas memeriksa semua bagian atau difisi dalam perusahaan apakah sudah sesuai dengan standart yang telah ditetapkan atau tidak, serta mencari solusi atas masalah yang terjadi dalam perusahaan. Audit internal juga diharapkan dapat melaporkan hasil temuannya kepada manajemen puncak serta memberikan solusi atau merekomendasikan langkah-langkah yang harus diambil oleh perusahaan untuk memecahkan masalah tersebut (jobdesc.net).

Seperti yang terjadi pada kasus bank century, bank ini hampir pailit dan menghabiskan biaya penyelamatan iivisi penjamin LPS poltak menyampaikan bahwa biaya penyelamatan bank century lebih besar yaitu Rp.15,363 triliun dibanding dengan kerugian yang dialami jika tidak menyelamatkan bank century tersebut yaitu sebesar RP.195,354 miliar. Yang menjadi terdakwah dalam kasus tersebut yaitu budi mulya selaku mantan deputi gubernur bank indonesia, namun dewan gubernur bank indonesia tidak menginginkan bank century ditetapkan sebagai bank gagal yang nantinya akan ditutup, dewan gubernur tetap menginginkan bank century tetap beroperasi itulah alasan kenapa bank century tetap bisa dioperasikan. Meskipun demikian bank century ternyata masih mempunyai hutang yang jatuh tempo senilaiRp.859 miliar dan nilai tersebut melebihi nilai fasilitas pendanaan jangka pendek yang telah diberkan oleh bank indonesia, dan rasio kecukupan modal bank century juga menjadi $-3,53$ persen. Kasus bank century dinyatakan sebagai bank gagal yang berdampak sistemik (m. Republika.com).

Khorismawati, N. DKK.. (2013:8) Berdasarkan penelitian yang dilakukan dengan judul pengaruh peranan audit internal dan penerapan good corporate governance untuk mengantisipasi terjadinya fraud pada PT.United Tracktors menyatakan bahwa hasil hipotesis yang diajukan dalam penelitian yaitu peranan audit internal dan penerapan good corporate governance berpengaruh terhdap upaya mengantisipasi fraud, hal ini juga dibuktikan dengan perhitungan koefisien determinasi yang memperoleh nilai $85,9 \%$ yang artinya peranan audit internal dan penerapan good corporate governance berkontribusi besar dalam upaya mengantisipasi terjadinya fraud.

Sektor perbankan merupakan bidang yang seakan tidak terhindarkan dari kasus fraud bahkan bisa dikatakan rentan terjadi fraud, dimana dalam sektor perbankan yang dikelola yaitu uang masyarakat dan kemungkinan ada pihak- pihak yang melakukan kecurangan. Terdapat banyak kasus yang mungkin terjadi di sektor perbankan diantaranya kasus kredit, melakukan pencatatan yang fiktif, korupsi, serta penyalah gunaan aset (sri, 2016). Oleh karena itu peneliti tertarik melakukan penelitian disektor perbankan dan berdasarkan latar belakakang diatas peneliti melakukan penelitian dengan judul Peranan Auditor Internal Dalam Upaya Pencegahan Fraud Study Kasus Perusahaan Perbankan Yang Terdaftar Di Bursa Efek Indonesia. Penelitian ini bertujuan untuk mengetahui seberapa besar peran auditor internal dalam mencegah fraud serta upaya apa saja yang dilakukan auditor internal dalam mencegah terjadinya fraud.

\section{TINJAUAN PUSTAKA}

\section{Definisi Fraud}

Menurut Diaz Priantara (2013:4) fraud adalah suatu perbuatan sengaja atau membohongi, suatu tipu daya atau cara-cara yang tidak jujur untuk mengambil atau menghilangkan uang, harta, atau hak yang sah milik orang lain baik karena suatu tindakan atau dampak yang fatal ari tindakan itu sendiri. Sedangkan Menurut Mark.f.zimbelman Dkk. (2014:7) Kecurangan merupakan semua tindakan yang dilakukan seseorang untuk mengambil keuntugan dari orang lain dengan cara yang tidak benar, kecurangan juga bisa diartikan semua hal yang mencangkup perbuatan yang keliru dan merugikan orang lain. 
Terdapat beberapa hal yang mendorong seseorang untuk melakukan kecurangan dan hal yang paling umum yang menjadi pendorong seseorang melakukan kecurangan yaitu yang disebut triangel fraud. Dalam triangel fraud terdapat tiga elemen yaitu:

1. Tekanan

Tekanan yang dirasakan seseorang menjadi pemicu dalam melakukan fraud, tekanan yang dirasakan terbagi menjadi beberapa yaitu: tekanan keuangan, tekanan untuk meakukan, dan tekanan terkait pekerjaan.

2. Kesempatan

Kesempatan yang dimiliki seseorang juga menjadi pemicu dalam terjadinya kasus fraud, seorang pegawai perusahaan mempunyai kesempatan untuk melakukakan kecurangan saat dalam perusahaan tidak mempunyai pengendalian internal yang baik, ketidak mampuan untuk menilai kualitas kerja, kegagalan untuk memberikan sanksi tegas terhadap pelaku kecurangan dan kurangnya upaya melakukan jejak audit.

3. Rasionalisasi

Rasionalisasi menjadi elemen penting dalam terjadinya fraud dimana pelaku mencari pembenaran atas tindakannya, misalnya masa kerja pelaku cukup lama dan dia berhak mendapatkan lebih dari yang telah dia dapatkan sekarang (posisi, gaji, promosi, dan lain-lain) atau perusahaan telah mendapatkan keuntungan yang sangat besar dan tidak ada salahnya jika pelaku mengambil bagian sedikit dari keuntungan tersebut.

\section{Klasifikasi Fraud}

Menurut Association Of Certified Fraud Examiners (ACFE) jenis-jenis fraud terbagi menjadi tiga yaitu:

1. Penyalahgunaan aset

Penyalahgunaan aset merupakan tindak kecurangan dimana pelaku yang tidak lain adalah karyawan perusahaan mengambil atau menyalah gunakan aset yang seharusnya hanya digunakan untuk kepentingan perusahaan, dengan kata lain karyawan tersebut menggunakan aset untuk kepentingan pribadi bahkan terkadang ada yang memindahkan aset ketangan pribadi.

2. Kecurangan laporan keuangan

Kecurangan laporan keuangan yaitu segala hal yang dilakukan seseorang untuk memanipulasi data-data dari laporan keungan sehingga tidak menunjukkan keadaan yang sebenarnya. Hal ini dilakukan untuk menutupi keadaan perusahaan yang mulai memburuk, biasanya dalam kecurangan laporan keuangan terdapat indikasi sebagai berikut:
a. Melakukan pencatatan yang fiktif
b. Menyajikan laba yang lebih besar dari yang sebenarnya
c. Memalsukan dokumen

3. Korupsi

Korupsi merupakan kecurangan yang dilakukan seseorang dalam hal penyalahgunaan jabatan untuk mengambil keuntungan secara pribadi. Menurut tuannakotta terdapat beberapa ciri dari korupsi yaitu seseorang yang mempunyai kekuasaan dalam sebuah organisasi, orang tersebut mempunyai wewenang, tidak harus mempertanggungjawabkan tindakan yang dilakukannya kepada pihak lain, dan dilakukan ditempat yang tidak terlalu besar atau terbuka.

Menurut Tugiman, H. (2011:32) fraud meliputi suatu susunan ketidak beresan dan perbuatan ilegal yang merupakan suatu muslihat yang dilakukan untuk keuntungan atau kerugian organisasi, dan yang dilakukan oleh orang diluar atau didalam organisasi. Kecurangan yang bertujuan menghasilkan keuntungan organisasi pada umumnya menghasilkan suatu keuntungan secara tidak juju atau tidak wajar yang mungkin dapat 
menimbulkan kerugian bagi pihak diluar oranisasi. Pelaku jenis ini memperoleh keuntungan secara tidak langung, karena pada umumnya keuntungan pribadi akan bertambah bila organisasi mendapatkan kentungan. Berikut contoh kecurangan yang dilakukan oleh orang didalam organisasi:

1. Penjualan atau penyerahan harta fiktif atau yang digambarkan secara keliru

2. Penyajian atau penilaian terhadap transaksi, harta, kewajiban, pendapatan yang sengaja dilakukan secara tidak benar

3. Penetapan pengalihan harga yang dengan sengaja dilakukan dengan tidak benar.dan lain sebagainya.

Kecurangan yang menimbulkan suatu kerugian bagi organisasi pada umumnya dilakukan untuk keuntugan secara langsung atau tidak langsung bagi pegawai, individu diluar organisasi atau organisasi lain. Contoh fraud jenis ini yaitu:

1. Penerimaan suap atau komisi gelap

2. Pengambilan suatu transaksi yang potensial menghasilkan keuntungan bagi pegawai atau pihak luar organisasi.

3. Kesengajaan menyembunyikan atau menyajikan data dengan tidak benar.

\section{Pencegahan Fraud}

Pencegahan kecurangan bisa dimulai dari pihak intern khususnya pemimpin perusahaan, sikap dan tindakan dari pimpinan akan ditiru oleh para karyawan sehingga diharapkan seorang pemimpin bisa bersikap jujur dan bertanggung jawab. Untuk bisa mencegah kecurangan, perusahaan harus mempunyai internal control yang bagus, selain itu dalam perusahaan harus menanamkan sikap anti fraud, dan upaya dalam menilai resiko terjadinya fraud (Tuannakotta 2010). Pencegahan fraud terdiri atas berbagai tindakan yang dilakukan untuk memperkecil kemungkinan terjadinya fraud, membatasi atau memperkecil kerugian yang mungkin timbul bila terjadi fraud. Mekanisme utama bila terjadi fraud adalah pengawasan tanggung jawab yang utama untuk menetapkan dan mengembangkan pengawasan yang terletak pada manajemen (Hiro, T;2011).

\section{Audit Internal}

Audit internal merupakan kegiatan assurance dan konsultasi yang dilakukan secara independen dan objektif yang dirancang untuk memberikan nilai tambah dan meningkatkan kegiatan operasi organisasi. Audit internal membantu organisasi mencapai tujuannya melalui suatu pendekatan yang sistematik dan teratur untuk mengevluasi dan meningkatkan efektifitas pengelolalaan resiko, pengendalian dan tatakelola.

\section{Tipe Audit}

Terdapat beberapa tipe penugasan audit yang dilakukan oleh auditor internal, yaitu sebagai berikut:

1. Audit keuangan

Audit keuangan adalah audit yang dilakukan terhadap transaksi, catatan akuntansi dan laporan keuangan baik ditingkat bagian /departemen atau laporan keuangan perusahaan pusat. Pada aspek pengendalian auditor meamstikan transaksi tersebut telah diotorisasi, disajikan dalam catatan akuntansi dan diungkapkan dalam laporan keuangan secara tepat dan akurat. 
2. Audit non keuangan

a. Audit kepatuhan

Audit kepatuhan dilakukan untuk menentukan apakah akifitas suatu entitas telah mematuhi hukum, kebijakan, prosedur yang dibuat oleh organisasi dan oleh pihak-pihak yang mengikat. Auditor biasanya memberikan rekomendasi untuk perbaikan dalam pengendaliandan proses yang digunakan untuk mematuhi berbagai peraturan.

b. Audit kinerja

Audit kinerja dilakukan untuk menetukan bagaimana suatu entitas mengelola penggunaan sumber daya secara ekonomis, efektif dan efisien dalam memenuhi misi dan tujuan entitas, pengelolaan sumber daya yanga dimaksud meliputi prosedur, proses, dan kinerja personil yang melaksanakan fungsi pengelolaan tersebut.

c. Audit pengadaan

Audit pengadaan adalah salah satu fungsi audit internal yang mengawasi pelaksanaan pengadaan barang/jasa dilingkungan entitas. Pengawasan yang dilakukan oleh auditor internal meliputi seluruh proses pengadaan barang/jasa dari pemeriksaan Rencana Anggaran dan Biaya (RAB) sampai dengan penyerahan barang dan jasa yang diminta. Audit fisisk merupakan bagian dari audit kepatuhan dan lebih efektif untuk mencegah timbulnya fraud.

\section{Prinsip-Prinsip Kode Etik The International Internal Audit (IIA)}

Auditor internal diharapkan dapat mengaplikasikan dan mempertahankan prinsipprinsip berikut:

1. Intergritas

Auditor internal membangun kepercayaan dan memberikan dasar kepercayaan terhadap penilaian yang dilakukan

2. Objektifitas

Auditor internal menunjukkan tingkatan objektifitas profesional tertinggi dalam mengumpulkan, mengevaluasi dan mengkomunikasikan informasi tentang aktivitas atau proses yang sedang diperikasa. auditor internal membuat penilaian yang seimbang terhadap semua kejadian yang relevan dan tidak dipengaruhi oleh kepentingan pribadi maupun kepentingan orang lain dalam membuat penilaian.

3. Kerahasiaan

Auditor internal menghormati nilai dan kepemilikan informasi yang diterima dan tidak mengungkap informasi tanpa otoritas yang sesuai, tanpa jaminan yang sah atau tuntutan profesional. Auditor tidak diperkenankan mendiskusikan hal apapun yang berkaitan dengan audit yang dilakukan terhadap pihak luar yang tidak termasuk dalam staf audit.

4. Kompetensi

Auditor internal menerapkan pengetahuan,keahlian dan pengalaman yang diperlukan dalam menjalankan tugas dan tanggung jawabnya pada jasa layanan audit internal.

\section{Standar Profesi Audit Internal}

The international Internal Audit Standards Board (IIASB) telah merilis revisi terbaru, yang efektif diberlakukan mulai januari 2013 sesuai dengan pertimbangan dan persetujuan The International Professional Practice Framework Oversigt Council (IPPFOC). Dengan diterbitkannya standart tersebut berarti baik audit internal maupun SKAI wajib mematuhi standar-standar terkait dengan integritas. 
Dokumen standar IIA yang dapat diterapkan oleh auditor internal dikenal dengan standar internasional untuk praktik profesional auditor internal (SIPPAI). Tujuannya yaitu untuk:

1. Menggambarkan prinsip-prinsip dasar yang mempresentasikan praktik audit internal yang seharusnya.

2. Memberikan kerangka kerja untuk melaksanakan dan mengembangkan berbagai aktifitas audit internal yang mempunyai nilai tambah.

3. Memberikan kerangka dasar pengukuran kinerja audit internal.

4. Meningkatkan proses dan operasi organisasi.

Para pemeriksa internal bertanggung jawab mendukung pencegahan kecurangan dengan cara mennguji dan mengevaluasi kecukupan dan keefektifan sistem pengendalian internal, sesuai dengan tingkat kerugian atau resiko yang potensial dalam berbagai segmen kegiatan organisasi. Dalam melaksanakan tanggung jawab ini, para pemeriksa berdasarkan keahliannya harus menetukan beberapa hal sebagai berikut:

1. Apakah lingkungan atau situasi organisasi membantu mengembangkan kesadaran pengawasan.?

2. Apakah tujuan dan sasaran organisasir yang realistis telah ditetapkan?

3. Apakah telah tedapat suatu keijaksanaan tertulis, misalnya dalam bidang kepegawaian yang menggambarkabuatann berbagai perbuatan yang boleh dilakukan dan tindakan yang akan dikenakan sanksi apabila terjadi pelanggaran.?

4. Apakah kebijaksanaan yang tepat tentang otorisasi berbagai transaksi etelah ditetakan dan dilaksanakan.?

5. Apakah kebijaksanan, pelaksanaan prosesedur, laporan dan berbagai mekanisme lainnya telah dikembangkan untuk memonitor beragai kegiatan dan melindungi berbagai harta, khususnya di area yang memiliki resiko tinggi.?

\section{METODE PENELITIAN}

Penelitian ini merupakan penelitian deskriptif kualitatif yaitu penelitian yang bertujuan untuk mendeskripsikan suatu keadaan atau objek yang menjadi perhatian dalam kegiatan penelitian secara sistematis menggunakan data dokumentasi berupa data-data atau informasi yang diperoleh dari annual report perusahaan perbankan.

Jenis dan sumber data dari penelitian ini yaitu jenis datanya data kualitatif, dimana data tersebut berupa informasi yang menggambarkan keaadan dari perusahaan perbankan tersebut, sumber data dari penelitian ini yaitu data sekunder yang berupa informasi audit internal perusahaan yang diambil dari annual report perusahaan perbankan di situs resmi www.idx.co.id.

\section{Definisi operasional}

Syaiful bahri (2018:137) definisi operasional adalah penjelasan deinisi dari variabel yang telah dipilih oleh peneliti. Operasional adalah penentuan construt menjadi variabel yang dapat diukur. Peneliti perlu menetapkan cara pengukuran variabel tersebut agar memperoleh nilai yang tepat untuk variabel tersebut.

\section{Variabel independen (variabel X)}

Variabel independen yaitu variabel bebas, variabel yang dapat mempengaruhi variabel lain. Dalam penelitian ini variabel independennya yaitu Audit internal merupakan kegiatan assurance dan konsultasi yang dilakukan secara independen dan objektif yang dirancang untuk memberikan nilai tambah dan meningkatkan kegiatan operasi organisasi. 
Audit internal membantu organisasi mencapai tujuannya melalui suatu pendekatan yang sistematik dan teratur untuk mengevluasi dan meningkatkan efektifitas pengelolalaan resiko, pengendalian dan tatakelola

\section{Variabel dependen (variabel Y)}

Variabel dependen merupakan variabel terikat, dalam penelitian ini variabel dependennya yaitu Pencegahan fraud. Pencegahan fraud terdiri atas berbagai tindakan yang dilakukan untuk memperkecil kemungkinan terjadinya fraud, membatasi atau memperkecil kerugian yang mungkin timbul bila terjadi fraud. Mekanisme utama bila terjadi fraud adalah pengawasan tanggung jawab yang utama untuk menetapkan dan mengembangkan pengawasan yang terletak pada manajemen

\section{Populasi dan sampel}

Populasi dari peneitian ini yaitu perusahaan perbankan yang terdaftar di Bursa Efek Indonesia pada tahun 2017 sedangkan Sampel yang digunakan dalam penelitian ini yaitu porposive samping, purposive sampling merupakan teknik pemilihan sampel dengan didasarkan pada kriteria-kriteria tertentu dengan tujuan untuk memberikan informasi yang maksimal. Kriteria yang ditetapkan peneliti dalam pemilihan sampel yaitu:

1. Perusahaan perbankan yang menjadi milik negara (BUMN)

2. Perusahaan perbankan yang mempunyai audit internal

3. Perusanhaan perbankan yang sadar akan pencegahan kecurangan.

\section{Teknik pengumpulan data}

Dalam penelitian ini, teknik pengumpulan data melalui dokumentasi yaitu mengambil data tentang audit internal dan pencegahan fraud berupa annua report perusahaan perbankan tahun 2017. Peneliti mengunduhnya di situs resmi www.idx.co.id.

\section{Teknik Analisis Data}

Dalam penelitian ini peneliti menggunakan metode deskriptif, dimana peneliti menggambarkan atau menjelaskan tentang data yang diperoleh tentang peranan uadit internal dalam mencegah fraud serta membandingkan pencegahan fraud oleh auditor da apa saja upaya yang telah dilakukan perusahaan perbankan dalam mencegah fraud.

Tanggung jawab yang harus dipenuhi auditor internal dapat dievaluasi dengan beberapa hal dibawah ini:

1. Apakah lingkungan atau situasi organisasi membantu mengembangkan kesadaran pengawasan.?

2. Apakah tujuan dan sasaran organisasir yang realistis telah ditetapkan

3. Apakah telah terdapat suatu keijaksanaan tertulis, misalnya dalam bidang kepegawaian yang menggambarkan berbagai perbuatan yang boleh dilakukan dan tindakan yang akan dikenakan sanksi apabila terjadi pelanggaran.

4. Apakah kebijaksanaan yang tepat tentang otorisasi berbagai transaksi etelah ditetakan dan dilaksanakan.

5. Apakah kebijaksanan, pelaksanaan prosesedur, laporan dan berbagai mekanisme lainnya telah dikembangkan untuk memonitor beragai kegiatan dan melindungi berbagai harta, khususnya di area yang memiliki resiko tinggi. 


\section{PEMBAHASAN}

Dari populasi yang dijadikan objek oleh peneliti yaitu perusahaan perbankan yang terdaftar di Bursa Efek Indonesia terdapat 43 perusahaan perbankan, kemmuadian peneliti menggunakan purposive sampling untuk menentukan sampel yang akan digunakan dan peneliti memperoleh 4 perusahaan perbankan yang akan dijadikan sampel. Perusahaan yang dijadikan sampel antara lain: Bank Negara Indonesia, Bank Rakyat Indonesia, Bank Tabungan Negara, dan Bank Mega Indonesia.

Tabel evaluasi kerja audit internal

\begin{tabular}{|c|c|c|c|c|}
\hline $\begin{array}{l}\text { evaluasi kerja } \\
\text { audit internal }\end{array}$ & BRI & $\mathrm{BNI}$ & Bank Mandiri & BTN \\
\hline $\begin{array}{l}\text { Apakah } \\
\text { lingkungan atau } \\
\text { situasi } \\
\text { organisasi } \\
\text { membantu } \\
\text { mengembangka } \\
\text { n kesadaran } \\
\text { pengawasan.? }\end{array}$ & $\begin{array}{l}\text { pihak bank } \\
\text { telah } \\
\text { menyediakan } \\
\text { wistleblowwin } \\
\text { g system } \\
\text { sebagai tempat } \\
\text { pelaporan jika } \\
\text { terjadi fraud }\end{array}$ & $\begin{array}{l}\text { pihak bank } \\
\text { telah } \\
\text { menyediakan } \\
\text { pengendalian } \\
\text { gratifikasi } \\
\text { sebagai upaya } \\
\text { pencegahan } \\
\text { fraud }\end{array}$ & $\begin{array}{l}\text { Pihak bank } \\
\text { sudah } \\
\text { menyediakan } \\
\text { unit pengendali } \\
\text { gratifikasi dan } \\
\text { wistleblowwin } \\
\text { g system }\end{array}$ & $\begin{array}{l}\text { Pihak bank } \\
\text { sudah } \\
\text { menyediakan } \\
\text { wistleblowwin } \\
\text { g system dan } \\
\text { program } \\
\text { Awareness } \\
\text { pengendalian } \\
\text { gratifikasi }\end{array}$ \\
\hline $\begin{array}{l}\text { Apakah tujuan } \\
\text { dan sasaran } \\
\text { organisasir yang } \\
\text { realistis telah } \\
\text { ditetapkan }\end{array}$ & $\begin{array}{l}\text { interal audit } \\
\text { dalam bank } \\
\text { BRI telah } \\
\text { melaksanakan } \\
\text { audit reguler, } \\
\text { audit khusus } \\
\text { dan audit } \\
\text { tematik secara } \\
\text { terperinci }\end{array}$ & $\begin{array}{l}\text { tujuan dan } \\
\text { sasaran } \\
\text { organisasi } \\
\text { telah } \\
\text { direalisasi } \\
\text { dengan baik }\end{array}$ & $\begin{array}{l}\text { Internal Audit } \\
\text { telah } \\
\text { menetapkan } 6 \\
\text { audit Tematik, } \\
10 \text { audit } \\
\text { Umum, } 6 \text { audit } \\
\text { Mandatory, } 9 \\
\text { audit } \\
\text { Perusahaan } \\
\text { Anak, dan } 5 \\
\text { Kajian. }\end{array}$ & $\begin{array}{l}\text { tujuan dan } \\
\text { sasaran } \\
\text { organisasi telah } \\
\text { direalisasi } \\
\text { dengan baik }\end{array}$ \\
\hline $\begin{array}{l}\text { Apakah telah } \\
\text { terdapat suatu } \\
\text { keijaksanaan } \\
\text { tertulis, } \\
\text { misalnya dalam } \\
\text { bidang } \\
\text { kepegawaian } \\
\text { yang } \\
\text { menggambarkan } \\
\text { berbagai } \\
\text { perbuatan yang } \\
\text { boleh dilakukan } \\
\text { dan tindakan } \\
\text { yang akan } \\
\text { dikenakan } \\
\text { sanksi apabila } \\
\text { terjadi } \\
\text { pelanggaran. }\end{array}$ & $\begin{array}{l}\text { semua } \\
\text { kebijakan } \\
\text { tersebut telah } \\
\text { dijelaskan } \\
\text { diatur dalam } \\
\text { kode etik bank } \\
\text { BRI dan sanksi } \\
\text { yang akan } \\
\text { diterima oleh } \\
\text { pelaku jika } \\
\text { melanggar } \\
\text { kebijakan } \\
\text { tersebut }\end{array}$ & $\begin{array}{l}\text { semua } \\
\text { kebijakan } \\
\text { tersebut telah } \\
\text { dijelaskan } \\
\text { diatur dalam } \\
\text { kode etik bank } \\
\text { BRI dan } \\
\text { sanksi yang } \\
\text { akan diterima } \\
\text { oleh pelaku } \\
\text { jika melanggar } \\
\text { kebijakan } \\
\text { tersebut }\end{array}$ & $\begin{array}{l}\text { Sanksi } \\
\text { dikategorikan } \\
\text { ke dalam } 3 \\
\text { jenis yaitu } \\
\text { sanksi ringan, } \\
\text { sedang dan } \\
\text { berat. Setiap } \\
\text { pelanggaran } \\
\text { Kode Etik akan } \\
\text { dikenakan } \\
\text { sanksi sesuai } \\
\text { Peraturan } \\
\text { Disiplin } \\
\text { Pegawai yang } \\
\text { berlaku di } \\
\text { Bank Mandiri. }\end{array}$ & $\begin{array}{l}\text { semua } \\
\text { kebijakan } \\
\text { tersebut telah } \\
\text { dijelaskan } \\
\text { diatur dalam } \\
\text { kode etik bank } \\
\text { BTN akan } \\
\text { dikenakan } \\
\text { sanksi berupa } \\
\text { sanksi } \\
\text { administratif } \\
\text { dan sanksi } \\
\text { inansial }\end{array}$ \\
\hline
\end{tabular}




\begin{tabular}{|c|c|c|c|c|}
\hline $\begin{array}{l}\text { Apakah } \\
\text { kebijaksanaan } \\
\text { yang tepat } \\
\text { tentang otorisasi } \\
\text { berbagai } \\
\text { transaksi telah } \\
\text { ditetakan dan } \\
\text { dilaksanakan. }\end{array}$ & $\begin{array}{l}\text { semua tugas } \\
\text { audit telah } \\
\text { Sesuai dengan } \\
\text { standar } \\
\text { internasional } \\
\text { praktik } \\
\text { profesional } \\
\text { audi internal } \\
\text { dari IIA dan } \\
\text { SKAI telah } \\
\text { melaksanakan } \\
\text { tugasnya sesuai } \\
\text { dengan piagam } \\
\text { intern }\end{array}$ & $\begin{array}{l}\text { semua } \\
\text { kegiatan audit } \\
\text { internal } \\
\text { tercantum } \\
\text { dalam rencana } \\
\text { program audit } \\
\text { yang disusun } \\
\text { oleh Internal } \\
\text { Audit Division } \\
\text { (IAD) }\end{array}$ & $\begin{array}{l}\text { Internal Audit } \\
\text { telah menyusun } \\
\text { dan } \\
\text { menetapkan } \\
\text { rencana audit } \\
\text { tahun } 2017 \\
\text { yang sejalan } \\
\text { dengan fokus } \\
\text { utama Bank } \\
\text { Mandiri. } \\
\text { Semua } \\
\text { tercantum } \\
\text { dalam Annual } \\
\text { Audit Plan } \\
\text { (AAP) 2017 }\end{array}$ & $\begin{array}{l}\text { semua kegiatan } \\
\text { audit internal } \\
\text { tercantum } \\
\text { dalam AUDIT }\end{array}$ \\
\hline $\begin{array}{l}\text { Apakah } \\
\text { kebijaksanan, } \\
\text { pelaksanaan } \\
\text { prosesedur, } \\
\text { laporan dan } \\
\text { berbagai } \\
\text { mekanisme } \\
\text { lainnya telah } \\
\text { dikembangkan } \\
\text { untuk } \\
\text { memonitor } \\
\text { beragai kegiatan } \\
\text { dan melindungi } \\
\text { berbagai harta, } \\
\text { khususnya di } \\
\text { area yang } \\
\text { memiliki resiko } \\
\text { tinggi. }\end{array}$ & $\begin{array}{l}\text { SKAI secara } \\
\text { rutin } \\
\text { melakukan } \\
\text { pemantauan } \\
\text { pelaksanaan } \\
\text { komitmen } \\
\text { manajemen } \\
\text { untuk } \\
\text { memperbaiki } \\
\text { kelemahan } \\
\text { pengendalian } \\
\text { internal }\end{array}$ & $\begin{array}{l}\text { kurang adanya } \\
\text { pengembanga } \\
\text { n yang } \\
\text { dilakukan oleh } \\
\text { audit internal } \\
\text { terhadap hal- } \\
\text { hal yang } \\
\text { mempunyai } \\
\text { resiko tinggi }\end{array}$ & $\begin{array}{l}\text { Internal Audit } \\
\text { menerapkan } \\
\text { metodologi risk } \\
\text { based audit } \\
\text { dalam } \\
\text { melaksanakan } \\
\text { aktivitas } \\
\text { internal audit } \\
\text { dengan } \\
\text { memfokuskan } \\
\text { pada area yang } \\
\text { berisiko tinggi. }\end{array}$ & $\begin{array}{l}\text { kurang adanya } \\
\text { pengembangan } \\
\text { yang dilakukan } \\
\text { oleh audit } \\
\text { internal } \\
\text { terhadap hal- } \\
\text { hal yang } \\
\text { mempunyai } \\
\text { resiko tinggi }\end{array}$ \\
\hline
\end{tabular}

\section{Audit internal pada Bank Rakyat Indonesia}

Semua kegiatan dan tugas audit internal telah tertulis dalam Piagam Audit Intern (Internal Audit Charter) tertuang dalam Surat Keputusan Bersama Dewan Komisaris dan Direksi BRI Nokep: 08-KOM/BRI/08/2015; Nokep: S.17-DIR/AIN/08/2015 tanggal 11 Agustus 2015. Piagam Audit Intern disusun guna memberikan gambaran dan pedoman mengenai visi, misi, kedudukan, tugas dan tanggung jawab, wewenang, kode etik Auditor Intern, Independensi dan Objektivitas, dan ruang lingkup pekerjaan audit intern dalam organisasi. Berikut adalah tugas-tugas yang telah dilaksanakan audit internal Bank Rakyat Indonesia:

1. Membantu tugas Direktur Utama dan Dewan Komisaris dalam melakukan pengawasan dengan cara menjabarkan secara operasional baik perencanaan, pelaksanaan maupun pemantauan hasil audit.

2. Menyusun dan melaksanakan Perencanaan Audit Tahunan. 
3. Membuat analisis dan penilaian atas efisiensi dan efektivitas di bidang Keuangan, Akuntansi, Operasional, Sumber Daya Manusia, Pemasaran, Teknologi Informasi dan kegiatan lainnya melalui pemeriksaan langsung dan pengawasan secara tidak langsung.

4. Mengidentifikasi segala kemungkinan untuk memperbaiki dan meningkatkan efisiensi penggunaan sumber daya dan dana.

5. Memberikan saran perbaikan dan informasi yang obyektif tentang kegiatan yang diperiksa pada semua tingkatan manajemen.

6. Memantau, menganalisis dan melaporkan pelaksanaan tindak lanjut perbaikan yang telah disarankan.

7. Memberikan penilaian tingkat keyakinan kualitas pelaksanaan tugas atas proses manajemen risiko, sistem pengendalian intern dan tata kelola usaha telah dilaksanakan secara cukup dan efektif di seluruh Unit Kerja BRI.

8. Melaksanakan audit di semua Unit Kerja BRI

9. Melakukan pemeriksaan khusus apabila diperlukan.

Dalam upaya pencegahan fraud bank BRI telah memiliki dan melaksanakan Whistleblowing System (WBS) dengan membuka saluran pengaduan ke nomer telpon dan email tertentu yang dipasang/disediakan di setiap Kantor Perseroan dengan sebagai penanggung jawab akhir adalah Direktur Utama. Satuan Kerja Audit Internal (SKAI) bertugas untuk membantu dalam hal ini dan banyak kasus yang telah ditindaklanjuti atau yang sumber informasinya dari pengembangan WBS. Setiap 3 bulan sekali, Dewan Komisaris memantau dan memastikan bahwa WBS berjalan secara efektif dengan antara lain memanfaatkan laporan dari SKAI dan tindak lanjutnya Untuk menanamkan mindset integritas kepada seluruh pekerja. Auditor internal Bank BRI telah menjalankan tugas dengan baik, ini dibuktikan dengan upaya-upaya yang dilakukan dalam menindak kasus fraud dan pelanggaran lainnya. Dari 16 kasus fraud internal audit telah menyelesaikan 13 kasus sedangkan 3 kasus masih dalam proses penyelesaian. Penyimpangan yang lain juga sudah bisa diselesaikan walaupun belum semua terselesaikan tetapi sebagian besar sudah mampu diselesaikan dengan baik.

\section{Audit internal pada Bank Negara Indonesia}

Penyimpangan internal (Internal Fraud) adalah penyimpangan/kecurangan yang dilakukan oleh pengurus, pegawai tetap dan tidak tetap (honorer dan outsourcing) terkait dengan proses kerja dan kegiatan operasional Bank yang mempengaruhi kondisi keuangan Bank. Namun inernal fraud ini telah ditangani oleh audit internal, dari 15 kasus yang dilakukan oleh pegawai tetap dan 2 kasus yang dilakukan oleh pegawai tidak tetap semua kasus tersebut telah diselesaikan dengan baik, dan 2 kasus dari pegawai tetap telah ditangani oleh hukum.

Sosialisasi terkait Gratifikasi telah dilakukan, melalui penayangan artikel maupun informasi lain terkait dengan Gratifikasi pada Website bni.co.id, media cetak (Harian Kompas), serta media internal BNI antara lain BNI Forum (Pelaporan Penerimaan Gratifikasi), Surat Edaran kepada segenap Divisi/Satuan/Unit, Leaflet mengenai Gratifikasi, serta melalui sarana e-learning (berupa case study). Selama tahun 2017, terdapat 7 (tujuh) laporan penerimaan gratifikasi yang disampaikan oleh pelapor (dhi. Pegawai BNI) kepada Divisi Kepatuhan, yang selanjutnya laporan tersebut diteruskan kepada KPK. Laporan penerimaan gratifikasi yang disampaikan oleh Pelapor telah diteruskan kepada KPK kurang dari 30 hari kerja

Bank Tabungan Negara 
Internal Audit Division (IAD) telah menyusun rencana atau program kerja audit dan melaksanakan kegiatan audit sesuai dengan rencana yang telah disusun. Rencana program Kerja tersebut mencakup sifat dan cakupan audit, penilaian risiko proses bisnis (risk assessment), susunan dan jumlahpersonil tim audit, standar hari kerja efektif audit, lamanyawaktu standar hari audit, kebutuhan jumlah personil dan kualifikasi jabatan personil IAD, kondisi kualifikasi perosnil IAD, penilaian risiko dan pengembangan personil IAD. Kegiatan audit sepanjang tahun 2017 menghasilkan temuan audit sebanyak 2924 temuan. Hasil tersebut menunjukan jumlah yang semakin naik selama dua tahun terakhir. Banyaknya temuan membuat audit internal harus bekerja keras untuk menindak lanjutinya dan hasilnya dari 2.924 temuan yang telah diselesaikan oleh audit internal yaitu 2491 kasus dan yang masih dalam penanganan yaitu 433 kasus. Di tahun 2017 juga terdapat kasus internal fraud sebanyak 16 kasus dan semua kasus telah diselesaikan oleh audit internal, Peran auditor internal sudah cukup baik namun perlu ditingkatkan lagi.

\section{Efektivitas Pelaksanaan Kegiatan Audit Internal}

Kegiatan audit sebagaimana diatur dalam kebijakan Audit Internal Perseroan berdasarkan risk based audit telah diimplementasikan sejak tahun 2004 dan kemudian disahkan dalam Peraturan Direksi No.09/PD/DAI/2008 tanggal 30 April 2008 tentang Kebijakan Audit Intern Perseroan dengan perubahan terakhir pada PD No 08/PD/IAD/2013 tanggal 5 Desember 2013, merupakan segala bentuk kegiatan yang berhubungan dengan audit dan pelaporan hasil audit mengenai terselenggaranya struktur pengendalian secara terkoordinasi dalam setiap tingkatan manajemen. Kegiatan audit dan penilaian terhadap sistem pengendalian intern dapat memberi nilai tambah dan meningkatkan kualitas pengelolaan Perseroan dalam rangka mewujudkan bank yang sehat dan berkembang secara wajar, serta terpenuhinya kepentingan Perseroan dan masyarakat dalam hal pengelolaan dana secara baik. Efektivitas dapat ditunjukan dengan nilai tambah yang dihasilkan dan meningkatkan kualitas pengelolaan Perseroan yang dibuktikan dengan berbagai capaian kinerja Perseroan dan penghargaan yang diperoleh Perseroan sepanjang tahun 2017.

\section{Upaya pencegahan fraud}

Pihak bnk melaksanakan program Awareness pengendalian gratifikasi, sebagai bentuk implementasi kebijakan gratifikasi dan program anti korupsi melalui beberapa kegiatan diantaranya:

1. Penggunaan PIN "Tolak Gratifikasi” yang digunakan oleh seluruh insan BTN;

2. Sosialisasi Program Pengendalian Gratifikasi melalui kegiatan Anti Fraud kepada seluruh Insan Perseroan kantor pusat maupun kantor cabang;

3. Penerbitan Buku Saku Program Pengendalian Gratifikasi;

4. Penyempurnaan peraturan internal tentang Program Pengendalian Gratifikasi Perseroan sesuai rekomendasi Komisi Pemberantasan Korupsi (KPK);

5. Pengisian Complaince quiz oleh seluruh anggota dalam perusahaan yang didalamnya termasuk kuis tentang Pengendalian Gratifikasi;

Perusahaan juga telah menyediakan wistleblowwing system, sebagai tempat pelaporan jika tejadi fraud. Wistleblowwing system dalam bank tabungan negara ini dikepalai atau dikelola langsung oleh audit internal. Perusahaan juga membangun infrastruktur pendukung dalam menerapkan kebijakan WBS dimana pelapor dapat menyampaikan laporannya melalui kotak surat yang dikirim ke perusahaan serta dapat dikirim lewat e-mail. 


\section{Internal Audit pada Bank Mandiri}

Internal Audit telah menyusun dan menetapkan rencana audit tahun 2017 yang sejalan dengan fokus utama Bank Mandiri. Melalui Annual Audit Plan (AAP) 2017 Internal Audit ingin memastikan pertumbuhan bisnis Bank Mandiri dilakukan secara prudent dan diimbangi dengan penerapan tata kelola perusahaan yang kuat di seluruh area operasional sehingga dapat menopang pertumbuhan kinerja berkelanjutan, untuk mencapai tujuan menjadi Indonesia's best, ASEAN's prominent.

Menghadapi kondisi tersebut, dalam rencana audit tahun 2017 ini, Internal Audit telah menetapkan 6 audit Tematik, 10 audit Umum, 6 audit Mandatory, 9 audit Perusahaan Anak, dan 5 Kajian. Audit 2017 mencakup area-area yang signifikan dan relevan dengan kondisi dan tantangan yang dihadapi Bank, yaitu audit mengenai Credit Quality di segmen Wholesale, Small Business, Mikro dan KUR, Consumer Loan, Laporan Bulanan Bank Umum (LBU) \& Sistem Informasi Debitur (SID) serta Kehandalan infrastruktur dan Aplikasi e-channel. Internal Audit menerapkan metodologi risk based audit dalam melaksanakan aktivitas internal audit dengan memfokuskan pada area yang berisiko tinggi. Penerapan metodologi ini sesuai dengan kebutuhan organisasi, ketentuan Regulator dan best practices. Penerapan metodologi risk based audit membutuhkan kerjasama yang baik antara Internal Audit dengan Unit Kerja Manajemen Risiko Operasional dan Klien.

Unit Pengendali Gratifikasi (UPG) Bank Mandiri berada di Compliance Group, pada Corporate Governance \& Business Ethic (CGB) Departemen. UPG berfungsi melakukan pengendalian Gratifikasi di lingkungan Bank Mandiri yang dalam menjalankan tugasnya dibantu oleh Decentralized Compliance and Operational Risk dan Anti Money Laundering Officer. Adapun susunan organisasi UPG Bank Mandiri Pelaporan Gratifikasi di Bank Mandiri dilakukan oleh pegawai Bank Mandiri dengan mengirimkan email kepada UPG.

Pegawai Bank Mandiri yang menerima/menolak gratifikasi melaporkan penerimaan/penolakannya kepada UPG melalui sarana email paling lama 5 Hari Kerja setelah penerimaan/penolakan gratifikasi dengan mengirimkan formulir pelaporan gratifikasi yang bisa diperoleh melalui kantor KPK atau website KPK atau melalui file pada PTO Pengendalian Gratifikasi disertai dengan dokumen pendukung seperti foto barang, bukti acara serah terima, undangan dan dokumen pendukung lainnya. Setelah menerima laporan, UPG akan melakukan review dan mengelompokkan laporan gratifikasi apakah merupakan kewenangan Bank Mandiri atau kewenangan KPK. Sampai Desember 2017, jumlah laporan penerimaan/penolakan Gratifikasi sebanyak 137 laporan. Penerimaan Gratifikasi yang dilaporkan di antaranya berupa honorarium, barang elektronik, cinderamata dan makanan.

Sebagai upaya untuk memantau dan mengendalikan fraud pada pilar deteksi, Bank Mandiri menyediakan kebijakan whistleblowing system yang dinamakan "Letter to CEO (LTC)". LTC merupakan sarana laporan pengaduan fraud dari pegawai maupun pihak ketiga kepada Direktur Utama dengan menitikberatkan pada pengungkapan dari pengaduan untuk meningkatkan efektivitas penerapan sistem pengendalian fraud. Program LTC sebagai salah satu program Strategi Anti Fraud (SAF) yang bertujuan untuk:

1. Mendeteksi kejahatan fraud atau indikasi fraud dengan adanya laporan pegawai atau pihak ketiga Bank Mandiri, yang dapat disampaikan dengan mencantumkan baik secara jelas identitasnya maupun anonymous, yang selanjutnya dapat dilakukan proses investigasi ataupun tindakan tindak lanjut.

2. Mendorong awareness atau kepedulian seluruh pegawai untuk turut serta menjaga unit kerjanya dari kerugian akibat fraud sehingga kualitas pengawasan lebih baik dan rasa ikut memiliki (sense of belonging) pegawai menjadi lebih tinggi. 
Jika terdapat karyawan atau pihak lain dalam perusahaan melakukan pelanggaran perusahaan memberikan sanksi terhadap pealku tersebut. Sanksi dikategorikan ke dalam 3 jenis yaitu sanksi ringan, sedang dan berat. Setiap pelanggaran Kode Etik akan dikenakan sanksi sesuai Peraturan Disiplin Pegawai yang berlaku di Bank Mandiri, termasuk sanksi pidana yang telah ditetapkan dalam peraturan perundang-undangan.

\section{KESIMPULAN}

1. Dari analisis yang telah dilakukan, dapat disimpulkan bahwa audit internal mempunyai peran yang sangat penting dalam mencegah fraud. Audit internal dari keempat bank yang dijadikan sampel tersebut bisa menerapkan dan menjalankan rencana audit yang telah disusun serta memberikan rekomendasi yang bisa menyelesaikan permasalahan yang terjadi diperbankan tersebut. Semua kegiatan audit telah dicantumkan dalam piagam audit serta diatur oleh peraturan direksi. Setelah dilakukan auditpun, audit internal masih harus direview kembali oleh komite audit. SKAI secara rutin melakukan pemantauan pelaksanaan komitmen manajemen untuk memperbaiki kelemahan pengendalian internal serta Internal Audit menerapkan metodologi risk based audit dalam melaksanakan aktivitas internal audit dengan memfokuskan pada area yang berisiko tinggi agar bisa mencegah terjadinya fraud.

2. Dari keempat bank tersebut sudah terdapat upaya dalam mencegah fraud antara lain sudah menyediakan wistleblowwing system dan program Awareness pengendalian gratifikasi. Meskipun masih saja terdapat fraud atau penyimpangan lainnya namun audit internal sudah mampu untuk menangani kasus tersebut. Bagi karyawan atau pihak lain yang melakukan penyimpangan (fraud) maka akan dikenakan sanksi dikategorikan ke dalam 3 jenis yaitu sanksi ringan, sedang dan berat. Setiap pelanggaran Kode Etik akan dikenakan sanksi sesuai Peraturan Disiplin Pegawai yang berlaku di Bank Mandiri sedangkan di bank BTN terdapat sanksi administratif dan sanksi finansial. Jika terdapat kasus yang tidak bisa diselesaikan hanya dengan pemberian sanksi maka akan dibawa keranah hukum.

\section{SARAN}

1. Pihak bank tetap harus meningkatkan pengendalian internal serta pengawasan yang intens terhadap semua devisi atau kegiatan dalam bank

2. Audit internal harus memastikan bahwa semua kegiatan dalam operasional bank telah telah berjalan sebagaimana mestinya serta langsung melaporkan kepada direksi jika terdapat hal yang menyimpang. Pihak bank juga harus segera menindak lanjuti kasus fraud dan memberikan sanksi yang bisa membuat pelaku tidak akan mengulangi perbuatannya. 


\section{DAFTAR PUSTAKA}

Bahri, S. 2018, Metodologi Penelitian Bisnis-Lengkap dengan Teknik Pengolahan Data SPSS, Penerbit Andi, Yogyakarta.

http://www.jobdesc.net/job-desc/tugas-dan-job-deskripsi-internal-audit.html. diakses tanggal 21 januari 2019.

https://fraudster.weebly.com/cara-pencegahan-fraud.html.diakses pada tanggal 22 januari 2019.

https://www.idx.co.id. Diakses 23 januari 2019.

https://www.republika.co.id/berita/nasional/hukum/14/03/06/n20q0m-ini-kronologiskasus-bank-century. diakses tanggal 22 januari 2019.

Khorismawati, N., Rasyid, A., dan Salim, M. 2013. Pengaruh Peranan Audit Internal Dan Penerapan Good Corporate Governance Untuk Mengantisipasi Terjadinya Fraud (Pt. United Tractors).

Pua1, B.,Y. Sondakh, J. Dan Pangerapan, S. 2017. Evaluasi Fungsi Auditor Internal Dalam Pendeteksian Dan Pencegahan Fraud Pada Pdam Airmadidi. Jurnal Riset Akuntansi Going Concern 12(2), 2017, 452-469.

Tuannakotta, M. T.,2010, Akuntansi forensik dan audit investigasi, edisi 2, salemba empat,Indonesia.

Tugiman, H. 2011. Standar Profesional Audit Internal.

https://books.google.co.id/books?id=b3Fdd7SzGVYC\&printsec $=$ frontcover $\& d q=$ audit + int ernal \&hl=id\&sa=X\&ved=0ahUKEwjgt5n4fgAhVaiHAKHUdAZEQ6AEINDAC\#v=onepa ge\&q=audit\%20internal $\& f=$ false. Diakses tanggal 23 januari 2019.

Zamzami, S., DKK. 2013. Audit Internal Konsep Dan Praktek.

https://books.google.co.id/books?id=1oFYDwAAQBAJ\&pg=PA4\&dq=pencegahan + fraud + oleh + audit + internal $\& h l=i d \& s a=X \& v e d=0$ ahUKEwiigez $i-$

ofgAhUH5o8KHU87BoUQ6AEIMDAA\#v=onepage $\& q=$ pence ahan $\% 20$ fraud $\% 20$ oleh $\% 2$ Oaudit\%20internal\&f=false. Diakses tanggal 23 januari 2019.

Zimbelman, M.F. Dkk,2014, Akuntansi forensik, edisi 4, salemba empat, indonesia 